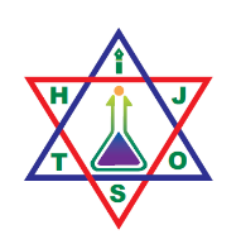

Himalayan Journal of Science and Technology, Vol. 3-4 (2020), 16-23

Himalayan Journal of Science and Technology

Original Article

\title{
Ethnomedicinal Knowledge of Kisan Community - A Case Study
}

\author{
${ }^{a}$ Manisha $K C^{*},{ }^{b}$ Nanda Bahadur Singh \\ aDepartment of Biology, Central Campus of Technology, Tribhuvan University, Dharan, Nepal \\ ${ }^{\mathrm{b} C e n t r a l}$ Department of Zoology, Tribhuvan University, Kirtipur, Nepal \\ *Corresponding email: manisha.kc@cct.tu.edu.np
}

\begin{abstract}
In the context of depleting indigenous knowledge and their values in the Kisan Community, they seem unaware of their culturally rich traditional practices of using animals and plants for medicinal purpose. It has been essential to document those knowledge of practices for future references. The paper tried to explore and document those knowledge and practices by the Kisan community of Mechinagar 9 and 11 of Jhapa, Nepal. For this purpose, the data were collected through interviews with key informants including conjurer (Dhami/Jhakri), elders of the society and also focal group discussions with the local people. Analysis of the data has shown that 29 animal species belonging to 24 families are used to treat 29 ailments and 57 plant species belonging to 37 families are used for treating 39 different ailments. The commonly treated ailments were common cold, cuts, wounds, diarrhoea, dysentery, etc.
\end{abstract}

\begin{tabular}{l}
\multicolumn{1}{c}{ Article Info } \\
\hline Article history: \\
Received date: 25 September 2019 \\
Accepted date: 24 July 2020 \\
\hline Keywords: \\
Kisan \\
Indigenous knowledge \\
Medico-ethnobiology
\end{tabular}

\section{Introduction}

The medicinal plant species have been considered as an important source of potentially therapeutic drugs (Cox \& Ballick, 1994). Worldwide more than 21,000 plant species have been recorded that acquires medicinal values (Shrestha et al., 2000). In context of Nepal, at least 1,600-1,900 species of medicinal plants are used in traditional medicinal practices (Tiwari 1994; Baral \& Kurmi, 2006).

An indigenous knowledge system is vulnerable to rapid change especially when young people acquires different life styles and values than their ancestors. The loss of indigenous knowledge cannot replenish, hence the documentation is important for the conservation of both cultural and biological diversity in Nepal. Hughes (1968) refers ethno-medicine as "those beliefs and practices relating to disease which are the products of indigenous cultural development and are not explicitly derived from the conceptual framework of modern medicines."

CBS (2011) has recognized 125 ethnic groups as indigenous nationalities living in different regions of Nepal, among which Kisan is one of the endangered indigenous tribal group and shows their number to be 1,739. The Eastern Development Region and the Western Development Region is considered as their major homeland with the total population of 1,056 and 656 respectively. In Jhapa, Kisan consider Mechinagar Municipality, as their main homelands. They have clustered settlements. The total population of Kisan in Jhapa is 1,037 of which 530 are male and 507 are female (CBS, 2012). Kisans are originally the inhabitants of Orissa, India who have migrated Nepal in search of good forest and cultivable land. The traditional name of these people is Kuntam. At present, however, they are known by various other names, such as Kuda, Kora, Mirdha, Morbha, Birhor, and Nagesia (http://www.ncard.org.np/categorydetail/Kisan.html). They have their own language called "Sadri" which is very close to Maithili language. They have their own culture, tradition and indigenous knowledge that have been preserved and transformed from ancient time to date. There is no any proof of what religion do Kisans belong to. The religious beliefs of Kisans are similar to that of Hindu to some extent. But, they do not visit the temples instead they believe nature as the incarnation of god and goddess and worship rivers, forests, hills 
and also different trees. Recently some family of Kisans also started following Christian religion.

The study aimed to explore ethnomedicinal knowledge of the Kisan community. Two major cluster settlements of Mechinagar 9 and 11 were selected as the study area (Fig. 1). The area lies near to the community forest which consists of Shorea robusta (sal), Schima wallichi (chilaune), Bambusa arundinaceaea (bamboo), Murrya koenigii (ashare), Dalbergia sissoo (sisau), Terminalia belerica (barra), etc. A variety of vegetation is available in the study area from trees to grasses. The wild animals such as peacock, deer, rabbit, bat, porcupine, elephant, wild boar, monkey, parrot, etc. are seen seasonally.

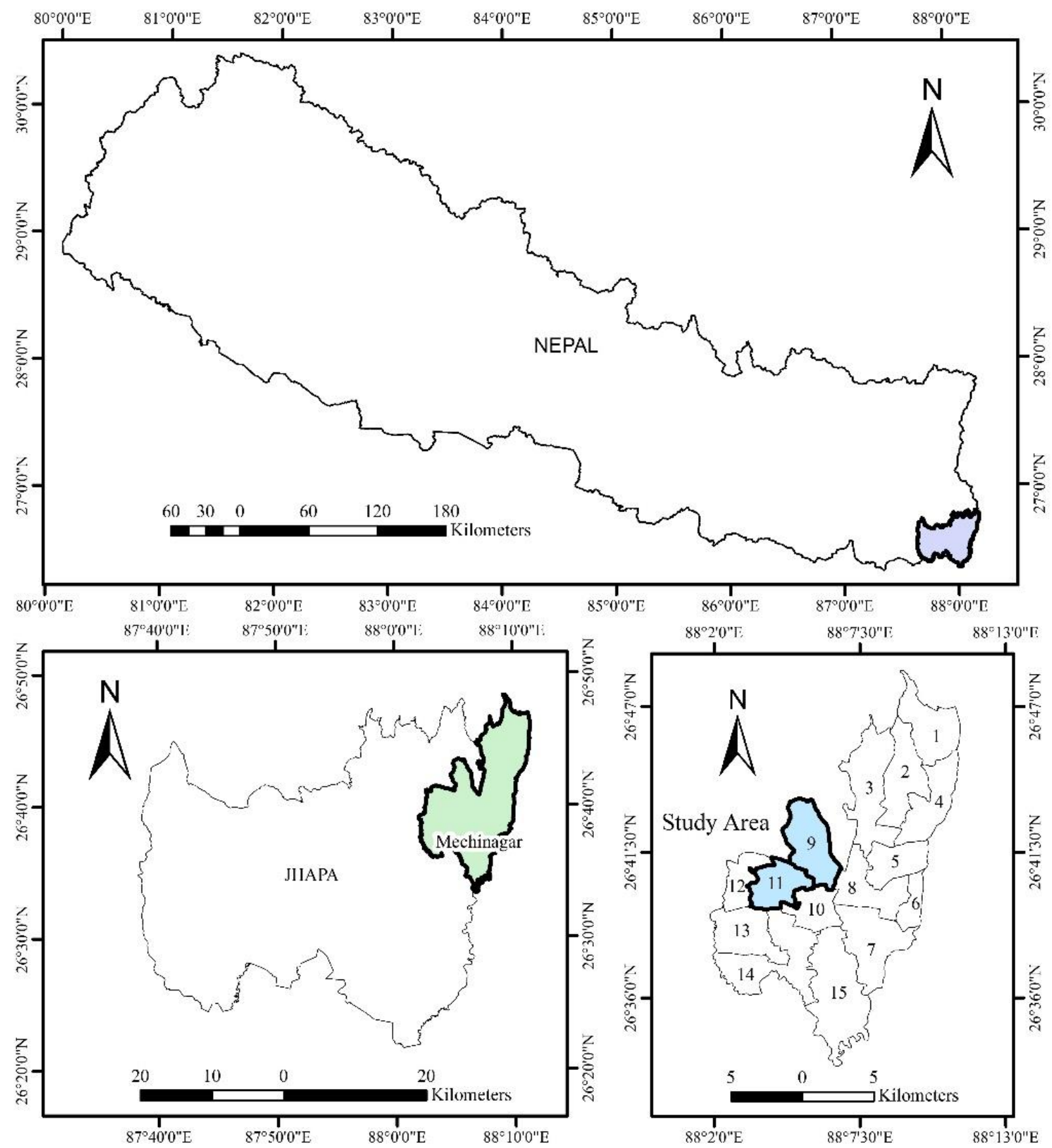

Fig. 1: Location map of study Area 


\section{Materials and Methods}

\subsection{Material}

To accomplish the study various primary and secondary data were collected. The lists of simple questions were prepared as questionnaire, so that respondents reply during the discussion could meet the objectives of the study.

\subsection{Methods}

The people of different age group were involved during the discussion. Key- informants for traditional medicinal practices are the local healers like Dhami, Jhakri and also some elderly persons.

A number of questions about animals and plants used as medicine for different diseases, traditional healing practices, indigenous knowledge system, etc. were discussed which were of immense help to complete this research work. Key- informants for traditional medicinal practices are the local healers like Dhami, Jhakri and also some elderly persons. Total informants, comprising 8 males and 4 females were identified between the age of 40 and 62 . They were selected on the basis of the knowledge of medicinal animals and plants for the self-medication and also for treating others. The collected samples in the field were identified with the help of experts from National Herbarium, Godawari. The animal species are classified into order, family, genera and species whereas the plant species are taxonomically classified into family, genera and species

\section{Results and Discussion}

People of Kisan community have been using different parts and products of various animals for treating several diseases as the traditional practice. The finding of the study revealed that, 29 animal species belonging to 24 families were used to treat 29 ailments. Along with the animals, the people also used 57 plant species belonging to 37 families for treating 39 different ailments. The detail list of medicinal animals and plants used is shown in the Table 1 and Table 2 respectively.

Table 1: Animal species used for medicinal purpose

\begin{tabular}{|c|c|c|c|c|c|}
\hline Family & Scientific name & $\begin{array}{l}\text { Part /product } \\
\text { used }\end{array}$ & Name of Ailments & ToD & AR \\
\hline Bovidae & Bos indicus & $\mathrm{G}$ & Body ache & MS & $\mathrm{A}$ \\
\hline Bovidae & Bubalus balis & $\mathrm{Fe}$ & Measles and scabies & I & A \\
\hline Suidae & Sus scrofa & M & Measles and diarrhea & I/GI & $\mathrm{O}$ \\
\hline Suidae & Sus domesticus & $\mathrm{F}$ & Pimples & I & A \\
\hline Carnidae & Canis aureus & M & Tuberculosis and arthritis & $\mathrm{R} / \mathrm{MS}$ & $\mathrm{O}$ \\
\hline Rhinolophidae & Rhinolopus sps & M & Asthma and night blindness & $\mathrm{R} / \mathrm{O}$ & $\mathrm{O}$ \\
\hline Equidae & Equus cabalus & $\mathrm{Um}$ & Epilepsy & $\mathrm{N}$ & I \\
\hline Manidae & Manis crassicaudata & S & Wound & I & A \\
\hline Hystricidae & Hystrix brachyura & $\mathrm{Ac}, \mathrm{Fe}$ & Abdomen pain and asthma & $\mathrm{GI} / \mathrm{R}$ & $\mathrm{O} / \mathrm{I}$ \\
\hline Charadridae & Vanellus indicus & M,E & Rheumatism and labour pain & MS & $\mathrm{O}$ \\
\hline Columbidae & Columba livia & $\mathrm{M}, \mathrm{Fe}$ & Common cold and blisters & $\mathrm{R} / \mathrm{I}$ & $\mathrm{O} / \mathrm{A}$ \\
\hline Phasinidae & Gallus Gallus & $\mathrm{M}, \mathrm{F}$ & Burns and body ache & I/MS & $\mathrm{O} / \mathrm{A}$ \\
\hline Phasinidae & Pavo cristatus & M & Diarrhoea and dysentery & GI & $\mathrm{O}$ \\
\hline Corvidae & Corvus spplendens & $\mathrm{B}$ & Wound of skin, Cracks of sole of foot & I & A \\
\hline Sturnidae & Acridotheres tritis & M & Piles & GI & $\mathrm{O}$ \\
\hline Ploceidae & Passer domesticus & M & Headache & $\mathrm{N}$ & $\mathrm{O}$ \\
\hline Cheloniidae & Aspideretes spp & S & Open wounds, Runche & I & $\mathrm{A} / \mathrm{Am}$ \\
\hline Varanidae & Varanus flavescens & $\mathrm{F}$ & Scabies & I & A \\
\hline Ranidae & $\begin{array}{l}\text { Haplobatrachus } \\
\text { igerinus }\end{array}$ & M & Malnutrition & - & $\mathrm{O}$ \\
\hline Claridae & Carias batrachus & M & Body ache & MS & $\mathrm{O}$ \\
\hline Amphipnoidae & Amphipnous cuchia & B & Gastritis & GI & $\mathrm{O}$ \\
\hline
\end{tabular}




\begin{tabular}{|c|c|c|c|c|}
\hline Canceridae & Cancer pagarus & $\mathrm{W}$ & Common cold & $\mathrm{R}$ \\
\hline Apidae & Apis dorsata & $\mathrm{H}$ & Body ache, Common cold & $\mathrm{MS} / \mathrm{R}$ \\
\hline Apidae & Apis indica & $\mathrm{H}$ & Body ache, Common cold & $\mathrm{MS} / \mathrm{R}$ \\
\hline Vesppidae & Vespa orientalis & $\mathrm{L}$ & Urine infection & GU \\
\hline Vesppidae & Vespa sylvestris & $\mathrm{L}$ & Cough and pneumonia & $\mathrm{R}$ \\
\hline Megascolecidae & Pheretima posthuma & $\mathrm{W}$ & Lactating enhancer & - \\
\hline Viviparidae & Bellamya bengalensis & $\mathrm{W}$ & Weakness and dizziness & $\mathrm{N}$ \\
\hline Unionidae & $\begin{array}{l}\text { Lamellidens } \\
\text { marginalis }\end{array}$ & M & Diarrhoea & GI \\
\hline
\end{tabular}

1) Part used: G Ghee, Fe Fecal, M Meat, F Fat, Um Umbilical Cord, S Shell, Ac Alimentary canal, E Egg, B Blood, W whole body, H Honey, L Larvae

2) ToD (Types of Diseases): MS Musculoskeletal, I Integumentary, GI Gastro intestinal, R Respiratory, O Ophthalmology, N nervous, GU Genital urinary,

3) AR (Administration Route): A Apply, O Oral, I Inhalation, Am Amulet

Table 2: Plant species used in medicinal purpose

\begin{tabular}{|c|c|c|c|c|c|c|c|}
\hline Family & Scientific name & L.F & $\begin{array}{l}\text { Parts } \\
\text { used }\end{array}$ & Medicinal use & ToD & $\begin{array}{c}\text { Form of } \\
\text { Medication }\end{array}$ & $\mathbf{A R}$ \\
\hline Acanthaceae & Justicia adhatoda & $\mathrm{S}$ & $\mathrm{R}, \mathrm{L}, \mathrm{F}$ & Asthma and urticaria & $\mathrm{R} / \mathrm{I}$ & Juice, paste & $\mathrm{O}$ \\
\hline Amaranthaceae & Achyranthes aspera & $\mathrm{H}$ & $\mathrm{L}$ & Piles, insect or snake bite & $\mathrm{GI} / \mathrm{N} / \mathrm{V}$ & Juice, paste & $\mathrm{O}$ \\
\hline Anacardiaceae & $\begin{array}{l}\text { Semecarpus } \\
\text { anacardium }\end{array}$ & $\mathrm{T}$ & $\mathrm{L}$ & Menstrual disorder & $\mathrm{Rp}$ & Juice & $\mathrm{O}$ \\
\hline Araceae & Acorus calamus & $\mathrm{H}$ & $\mathrm{Rh}$ & Sore throat and diarrhoea & R/GI & Dried & $\mathrm{O}$ \\
\hline Asclepioceacae & Calotropsis gigantum & S & $\mathrm{S}$ & Facture and sprain & MS & Latex & A \\
\hline Bignoniaceae & Oroxylum indicum & $\mathrm{T}$ & $\mathrm{B}, \mathrm{F}$ & $\begin{array}{l}\text { Wound and high blood } \\
\text { pressure }\end{array}$ & $\mathrm{I} / \mathrm{CV}$ & $\begin{array}{l}\text { Paste, cooked as } \\
\text { vegetable }\end{array}$ & $\mathrm{A} / \mathrm{O}$ \\
\hline Cannabaceae & Cannabis sativa & $\mathrm{H}$ & $\mathrm{L}$ & Diarrhoea and indigestion & GI & Juice & $\mathrm{O}$ \\
\hline Caryophyllaceae & Drymeria spp. & $\mathrm{H}$ & $\mathrm{W}$ & Cuts and sinus & $\mathrm{I} / \mathrm{OL}$ & Paste & $\mathrm{A} / \mathrm{I}$ \\
\hline Combretaceae & Terminalia bellirica & $\mathrm{T}$ & $\mathrm{Fr}$ & Cough & $\mathrm{R}$ & Raw & $\mathrm{O}$ \\
\hline Combretaceae & Terminalia chebula & $\mathrm{T}$ & $\mathrm{Fr}$ & Tooth ache and bleeding gums & $\mathrm{D}$ & Powder & A \\
\hline Compositae & Tegetes erecta & $\mathrm{H}$ & $\mathrm{L}$ & Cuts and fever & I & Juice, paste & $\mathrm{A} / \mathrm{O}$ \\
\hline Compositae & Artemisia vulgaris & $\mathrm{H}$ & W & Wound and cuts & I & Juice & A \\
\hline Convolvulaceae & Cuscuta reflexa & $\mathrm{C}$ & $\mathrm{T}$ & Jaundice & GI & Juice & $\mathrm{O}$ \\
\hline Cucurbitaceae & Momordica charantia & $\mathrm{C}$ & $\mathrm{Fr}$ & High blood pressure & $\mathrm{CV}$ & $\begin{array}{l}\text { Cooked } \\
\text { vegetable }\end{array}$ & $\mathrm{O}$ \\
\hline Dipterocarpaceae & Shorea robusta & $\mathrm{T}$ & $\mathrm{B}$ & Wound & I & Paste & A \\
\hline Euphorbiaceae & $\begin{array}{l}\text { Baliospermum } \\
\text { montanum }\end{array}$ & $S$ & $\mathrm{Sd}$ & Gastritis & GI & Raw & $\mathrm{O}$ \\
\hline Euphorbiaceae & Phyllanthus emblica & $\mathrm{T}$ & Fr & $\begin{array}{l}\text { Dysentery, stomach ache and } \\
\text { hair fall }\end{array}$ & GI & Powder & $\mathrm{O} / \mathrm{A}$ \\
\hline Euphorbiaceae & Phyllanthus amarus & $\mathrm{H}$ & $\mathrm{L}$ & Cuts and anemia & I & Paste, raw & $\mathrm{A} / \mathrm{O}$ \\
\hline Euphorbiaceae & Mallotus philippensis & $\mathrm{T}$ & Tw & Jaundice & GI & Paste & $\mathrm{O}$ \\
\hline Euphorbiaceae & Euphorbia royleana & $\mathrm{S}$ & $\mathrm{S}$ & Swelling, irritation (urticaria) & $\mathrm{Re} / \mathrm{I}$ & Latex & A \\
\hline Gentianaceae & Swertia angustifolia & G & $\mathrm{S}$ & Stomach ache and vomiting & GI & Juice & $\mathrm{O}$ \\
\hline Graminae & Cynodon dactylon & $\mathrm{H}$ & $\mathrm{W}$ & Fever and pneumonia & $\mathrm{R}$ & Paste & $\mathrm{O}$ \\
\hline Labiatae & Ocimum tenuiflorum & $\mathrm{H}$ & $\mathrm{L}$ & Fever, pneumonia and cough & $\mathrm{R}$ & Paste, Raw & $\mathrm{O}$ \\
\hline Labiatae & Mentha spicata & $\mathrm{H}$ & $\mathrm{L}$ & Stomach ache and gastritis & GI & Paste & $\mathrm{O}$ \\
\hline Labiatae & Leucas cephalotes & $\mathrm{S}$ & $\mathrm{R}$ & Diabetes & GI & Juice & $\mathrm{O}$ \\
\hline
\end{tabular}




\begin{tabular}{|c|c|c|c|c|c|c|c|c|}
\hline Leguminosae & Dolichas biflorus & $\mathrm{H}$ & $\mathrm{Sd}$ & $\begin{array}{l}\text { Arthritis, rheumatism, stone } \\
\text { and obstetrical haemorrhage }\end{array}$ & $\mathrm{MS} / \mathrm{Re}$ & Decoction & & $\mathrm{O}$ \\
\hline Leguminosae & $\begin{array}{l}\text { Trigonella } \\
\text { foenumgraecum }\end{array}$ & $\mathrm{H}$ & $\mathrm{Sd}$ & Cough & $\mathrm{R}$ & Powder & & $\mathrm{O}$ \\
\hline Leguminosae & Mimosa pudica & $\mathrm{H}$ & $\mathrm{R}$ & Diarrhoea & GI & Juice & & $\mathrm{O}$ \\
\hline Liliaceae & Asparagus racemosus & $\mathrm{S}$ & $\mathrm{W}, \mathrm{R}$ & $\begin{array}{l}\text { Fever, blood pressure and } \\
\text { lactation enhancer }\end{array}$ & $\mathrm{CV}$ & $\begin{array}{l}\text { Cooked } \\
\text { vegetable, raw }\end{array}$ & as & $\mathrm{O}$ \\
\hline Liliaceae & Aloe vera & $\mathrm{H}$ & $\mathrm{L}$ & Burns, pimples and hair fall & I & Latex & & A \\
\hline Liliaceae & Allium sativum & $\mathrm{G}$ & $\mathrm{Bu}$ & Gastritis & GI & Juice & & $\mathrm{O}$ \\
\hline Liliaceae & Allium сера & G & $\mathrm{Bu}$ & Ear pain & OL & Juice & & A \\
\hline Lycopodiaceae & Lycopodium clavatum & $\mathrm{H}$ & $\mathrm{R}$ & $\begin{array}{l}\text { Arthritis, rheumatism and } \\
\text { fever }\end{array}$ & MS & Raw & & $\mathrm{O}$ \\
\hline Meliaceae & Azadirachta indica & $\mathrm{T}$ & $\mathrm{L}$ & $\begin{array}{l}\text { Labour pain, bleeding } \\
\text { (obstetrical haemorrhage) and } \\
\text { urticaria }\end{array}$ & $\mathrm{Re} / \mathrm{I}$ & Decoction & & $\mathrm{O} / \mathrm{A}$ \\
\hline Menispermaceae & Tinospora sinensis & $\mathrm{C}$ & $\mathrm{S}, \mathrm{L}$ & Diarrhoea and stomach ache & GI & Paste & & $\mathrm{O}$ \\
\hline Moraceae & Ficus benghalensis & $\mathrm{T}$ & $\mathrm{S}$ & Rheumatism & MS & Latex & & A \\
\hline Musaceae & Musa paradisical & $\mathrm{H}$ & $\mathrm{Fr}, \mathrm{R}$ & $\begin{array}{l}\text { Diarrhoea, dysentery and burn } \\
\text { wound }\end{array}$ & $\mathrm{GI} / \mathrm{I}$ & Raw, Juice & & $\mathrm{O} / \mathrm{A}$ \\
\hline Mytraceae & Syzygium cumini & $\mathrm{T}$ & $\mathrm{Fr}$ & Diabetes and constipation & GI & Raw & & $\mathrm{O}$ \\
\hline Mytraceae & Psidium guajava & $\mathrm{T}$ & $\mathrm{L}$ & Diarrhoea and dysentery & GI & Raw & & $\mathrm{O}$ \\
\hline Mytraceae & Syzygium armaticum & $\mathrm{T}$ & $\mathrm{Bu}$ & Toothache & $\mathrm{D}$ & Powder & & A \\
\hline Oleaceae & Nyctanthes arbortristis & $\mathrm{T}$ & $\mathrm{L}$ & Ear pain & $\mathrm{OL}$ & Juice & & A \\
\hline Oxalidaceae & Oxalis corniculata & $\mathrm{H}$ & $\mathrm{L}$ & Gastritis and diarrhea & GI & Juice & & $\mathrm{O}$ \\
\hline Piperaceae & Piper nigrum & $\mathrm{T}$ & $\mathrm{Sd}$ & Cough & $\mathrm{R}$ & Powder & & $\mathrm{O}$ \\
\hline Poaceae & Saccharum spp. & G & $\mathrm{S}$ & Jaundice & GI & Juice & & $\mathrm{O}$ \\
\hline Punicaceae & Punica granatum & $\mathrm{T}$ & Fr, L & $\begin{array}{l}\text { Low blood pressure and } \\
\text { diarrhea }\end{array}$ & $\mathrm{CV} / \mathrm{GI}$ & Raw, Paste & & $\mathrm{O}$ \\
\hline Rhamnaceae & Ziziphus mauitiana & $\mathrm{S}$ & $\mathrm{R}$ & Fever and menstrual disorder & $\mathrm{Rp}$ & Juice & & $\mathrm{O}$ \\
\hline Rutaceae & Aegle marmelos & $\mathrm{T}$ & $\mathrm{Fr}$ & $\begin{array}{l}\text { Constipation, gastritis and } \\
\text { diabetes }\end{array}$ & GI & Raw, juice & & $\mathrm{O}$ \\
\hline Rutaceae & Citrus aurantifolia & S & $\mathrm{Fr}$ & Gastritic and vomiting & GI & Juice & & $\mathrm{O}$ \\
\hline Solanaceae & Datura metel & $\mathrm{S}$ & $\mathrm{L}$ & Burns & I & Paste & & A \\
\hline Solanaceae & Solanum tuberosum & $\mathrm{H}$ & $\mathrm{Tu}$ & Burns and skin darkening & I & Paste & & A \\
\hline Umbelliferae & Centella asiatica & $\mathrm{H}$ & $\mathrm{L}$ & Indigestion, cut and wounds & $\mathrm{GI} / \mathrm{I}$ & Paste & & $\mathrm{O} / \mathrm{A}$ \\
\hline Umbelliferae & Cuminum cyminum & $\mathrm{H}$ & $\mathrm{Sd}$ & Stomach ache & GI & Dried & & $\mathrm{O}$ \\
\hline Umbelliferae & Trachyspermum ammi & $\mathrm{H}$ & $\mathrm{Sd}$ & Cough and gastritis & R/GI & Dried & & $\mathrm{O}$ \\
\hline Urticaceae & Urtica dioica & $\mathrm{H}$ & $\mathrm{L}$ & $\begin{array}{l}\text { Menstrual } \\
\text { disorder(Menorrhagia) }\end{array}$ & $\mathrm{Rp}$ & $\begin{array}{l}\text { Cooked } \\
\text { vegetable }\end{array}$ & as & $\mathrm{O}$ \\
\hline Zingiberaceae & Zingiber officinale & $\mathrm{H}$ & $\mathrm{Rh}$ & Vomiting and cough & $\mathrm{GI} / \mathrm{R}$ & Raw & & $\mathrm{O}$ \\
\hline Zingiberaceae & Amomum subulatum & $\mathrm{H}$ & $\mathrm{Rh}$ & Stomach ache and vomiting & GI & Raw & & $\mathrm{O}$ \\
\hline Zingiberaceae & Curcuma angustifolia & $\mathrm{H}$ & $\mathrm{Rh}$ & $\begin{array}{l}\text { Cough, menstrual disorder and } \\
\text { skin darkening }\end{array}$ & $\mathrm{R} / \mathrm{Rp} / \mathrm{I}$ & Powder & & $\mathrm{O} / \mathrm{A}$ \\
\hline
\end{tabular}

1) L.F (Life forms): S Shrub, H Herb, T Tree, C Climber, G Grass,

2) Part used: R Root, L Leaves, F Flower, Rh Rhizomes, B Bark, S Stem, W Whole plant, Fr Fruit, T tendrils, Sd seeds, Tw Twig, Bu Bulb,

3) ToD (Types of Diseases): MS Musculoskeletal, I Integumentary, GI Gastro intestinal, R Respiratory, Rp Reproductive, Re Renal, V Vasular, CV Cardiovascular, D Dental, OL Otorhinolaryngo, N Nervous

4) AR (Administration Route): A Apply, O Oral, I Inhalation, 
The result also shows that among 29 zoo therapeutic animals, the share of mammals was $31 \%$, followed by aves $24 \%$, reptiles $7 \%$, amphibia $3 \%$, pisces $7 \%$, molluscs $7 \%$, arthropods $17 \%$ and annelids $3 \%$ (Fig. 2 ). The different parts and products used were ghee, meat, fat, umbilical cord, shell, alimentary canal, fecal matter, egg, blood, whole body, honey and larvae (Table 1). Similarly, among the 57 plant species, share of herb was $44 \%$, followed by tree $30 \%$, shrub $16 \%$, grass $7 \%$ and climber 5\% (Fig. 3).The different parts used were root, leaves, stem, rhizomes, etc. There were different forms of medication such as dried, powdered, decoction, raw, etc. (Table 2).

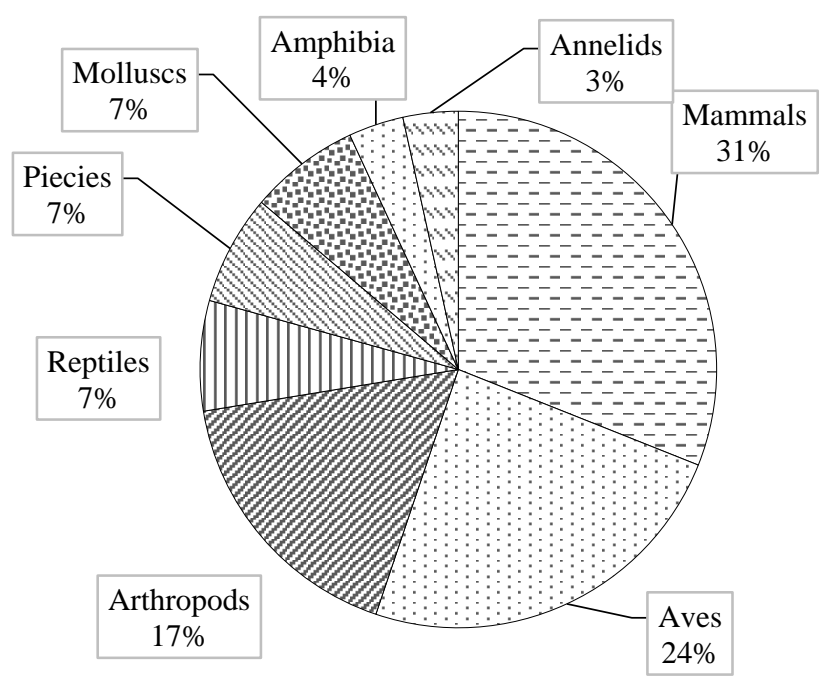

Fig. 2: The shares of animals belonging to different phylum and classes

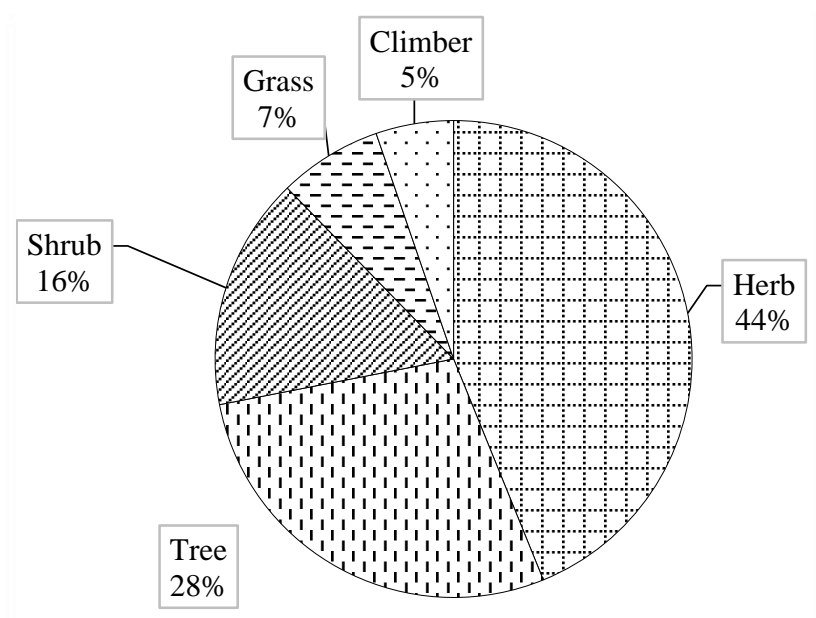

Fig. 3: The share of plants belonging to different life forms

Different sorts of ailments observed were categorized on the basis of affected parts of body. The results depicted that on total $30 \%$ were gastrointestinal, followed by $22 \%$ integumentary, $17 \%$ respiratory, $10 \%$ musculoskeleton, $4 \%$ nervous and cardiovascular, $5 \%$ reproductive, 3\% otorhinolaryngo, $2 \%$ dental and renal and $1 \%$ ophthalmology, Genital Urinary and Vascular. The ailments like fever, anaemia, malnutrition, labour pain, lactation enhancer and runche were not considered as diseases. The $\%$ of disease cured by different animals and plants is shown in Fig. 4.

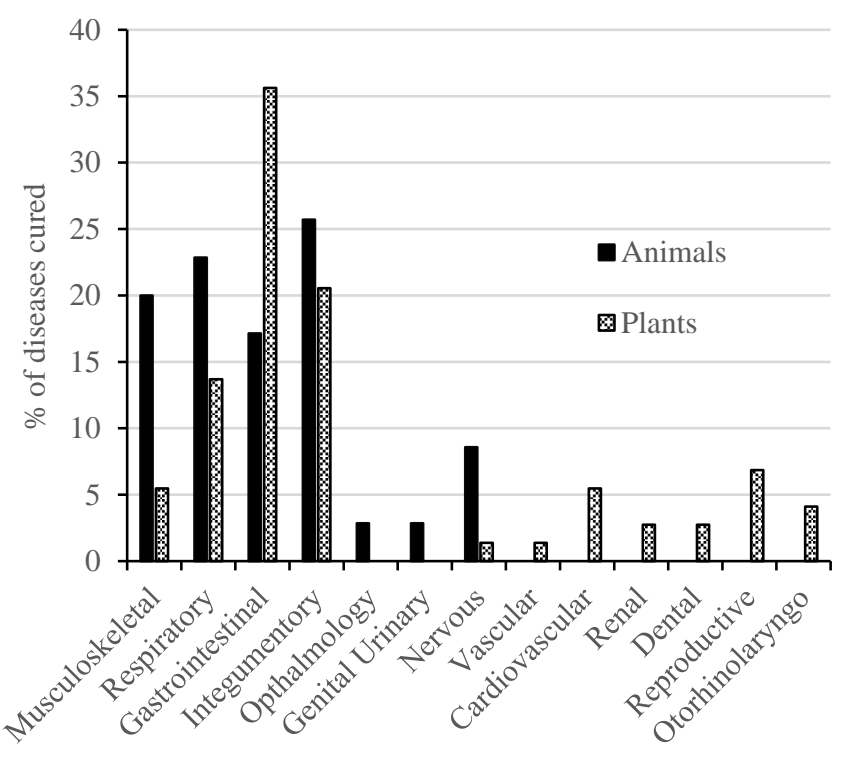

Types of diseases

Fig. 4: The different types of ailments treated

In the present study, both external and internal administration routes of the treatment were assessed. The internal medication included inhalation and oral absorption where the external medication included applying and protective amulet. The sharing of internal and external medications were $69 \%$ and $31 \%$ respectively. Among the total treatments, $66 \%$ were of oral types followed by $30 \%$ apply, $3 \%$ inhalation and $1 \%$ as protective amulet. The number of administration routes of the treatments for animals and plants is shown in Fig. 5.

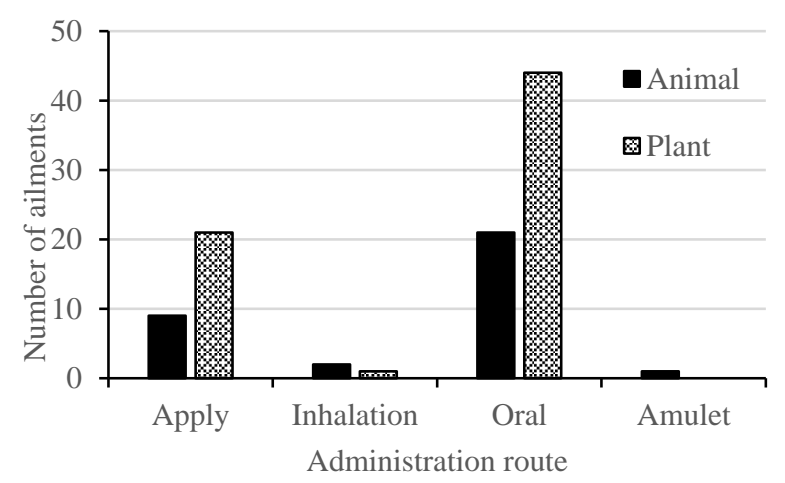

Fig. 5: The different methods of application of parts/products of animals and plants

The findings of this study have been supported by 
many other researchers, for example honey of Apis sps to treat body ache (Lohoni, 2010), stomach of Hystrix brachyura to cure asthma (Thapa, 2008; Lohoni, 2010; Lohoni, 2011 and Lohoni, 2012). Also Cuscuta reflexa and Saccharum spp. have been used for the treatment of jaundice IUCN (2004) and Thapa (2008). Similarly, Acharya (1996), Dangol (2010), Dangol \& Gurung (1999), DPR (2007), Gubhaju \& Ghimire (2010), Rai (2004), Shrestha (1988) and Thapa (1998) have observed the use of Cuscuta reflexa for treating jaundice while Ale et al. (2009) and Malla \& Chhetri (2009) have reported the use of Saccharum spp. for the same. Likewise in the present study, Psidium guajava and Phyllanthus emblica is used for treating dysentery which is supported by the study of Dangol (2010), Dangol \& Gurung (1999), Rai (2013) and DPR (2007).

Similarly, Asparagus racemosus is used as lactation enhancer and is well supported by Ale et al. (2009), Singh et al. (2011), Thapa (1998), Thapa (2008) and Rai (2013). Also, Calotropis gigantean is used for treating sprain, the similar use have been observed by Ale et al. (2009), Dangol (2010), Dangol \& Gurung (1999), Gubhaju \& Ghimire (2010) and Rai (2013). Similarly, Curcuma spp. is reported to be used for curing cough and is supported by Rai (2013).

\section{Conclusions}

The Kisan community of the area has traditionally been using 29 animals and 57 plants species for treating different ailments. The animal species are used to treat 29 ailments whereas, plants are used to treat 39 ailments. The traditional healer among the elderly people of this community, have better indigenous knowledge about practice of using animals and plants for medicinal purpose. As a modern change in daily practice with advance facilities has changed their livelihood. So, the use of traditional knowledge are gradually replaced by the modern system. The traditional healers who have knowledge of different medicinal practices are very few in number and the transfer of this valuable knowledge to their descendant is hindered. Hence, the use of traditional medicotherapy is losing its attraction and its importance too.

\section{Acknowledgments}

The author would like to appreciate the respective communities and each individual for their kind cooperation during the field survey. Also the authors appreciate the support of Mr. Bhim Kisan and Mr.
Parshuram Timsina for the necessary arrangement during the survey.

\section{Conflicts of Interest}

The authors state no conflicts of interest. The authors alone are responsible for composing the paper.

\section{Funding}

This research received no external funding or grants from any organizations.

\section{References}

Acharya, S. K. (1996). Folk uses of some medicinal plants of Pawan Nagar, Dang District. Journal of Natural History Museum, 15, 25-36.

Ale, R., Raskoti, B. B., \& Shrestha, K. (2009). Ethnobotanical knowledge of Magar community in Siluwa VDC, Palpa district, Nepal. Journal of Natural History Museum, 24(1), 58-71.

Baral, S. R., \& Kurmi, P. P. (2006). Compendium of medicinal plants in Nepal. Rachana Sharma.

Bhattachan, K. B. (2000). Tribals and Forests in Nepal: Whether Tribals or Animals \& the Dominant group Have Rights to Live. Sustainable Livelihood, South- Asia Conference on Legacy of Mahbub ul Haq- Human Development, Institute of Social Sciences, India.

CBS. (2012). Statistical year book of Nepal. CBS, Kathmandu, Nepal.

CBS. National Population and Housing Census 2011. National Report, NPHC, 1, pp. 270.

Dangol, D. R. (2010). Ethnobotany of Weeds of Chitwan District, Nepal. Journal of Natural History Museum, 25, 42-53.

Dangol, D. R., \& Gurung, S. B. (1999). Ethnobotanical study of Darai tribe in Chitwan district, Nepal. In Proceeding of III National conference on Science and Technology (pp. 8-11).

DPR. (2007). Medicinal Plants of Nepal, Bulletin of the Department of Plant Resources No 28. Government of Nepal, Ministry of Forest and Soil Conservation, Thapathali, Kathmandu, Nepal.

Gubhaju, M. R. \& Ghimire, S. K. (2010). Ethnomedicinal Practice in Dovan, Palpa Distict, Nepal. Journal of Natural History Museum, 25, 140-154. 
Hughes, C. (1968). Ethnomedicine. In: "International Encyclopedia of the Social Science 10" London: Crowell Collier and Macmillan Inc.

IUCN. (2004). National Register of Medicinal and Aromatic plants. International Union for Conservation of Natural Resources. Ministry of Forest and Soil Conservation.

Lohani, U. (2012). Zootherapeutic knowledge of two ethnic populations from Central Nepal. Studies on Ethno-Medicine, 6(1), 45-53.

Lohoni, U. (2010). Zootherapeutic Knowledge of Jirels of Dolakha District, Central Nepal. Journal of Natural History Museum, 25, 353-365.

Lohoni, U. (2011). Eroding Ethnozoological Knowledge among Magars in Central Nepal. Indian Journal of Traditional Knowledge, 10(3), 466-473.

Malla, B., \& Chhetri, R. B. (2009). Indigenous knowledge on ethnobotanical plants of Kavrepalanchowk district. Kathmandu University Journal of Science, Engineering and Technology, 5(2), 96-109.
Rai, S. K. (2004). Medicinal plants used by Meche people of Jhapa district, eastern Nepal. Our nature, 2(1), 27-32.

Shrestha, P. (1988). Contribution to the ethnobotany of the Tamangs of Kathmandu valley. Contributions to Nepalese Studies, 15(2), 247-266.

Thapa, C. B. (1998). Traditional uses of plants and their distribution in Shivapuri watershed and wildlife reserve area (Msc Thesis. Central Department of Botany, Kirtipur, Kathmandu, Nepal).

Thapa, S. (2008). Medico-ethnobiological knowledge of the Magars: A case study of Salija VDC, Parbat District, Central Nepal (Msc Thesis. Central Department of Environmental Science. Tribhuvan University, Kathmandu, Nepal).

Tiwari, N. N. (1999). Wild relatives of cultivated medicinal and aromatic plants (MAPs) in Nepal. In Proceedings of National Conference on Wild Relatives of Cultivated Plants in Nepal (pp. 141148).

http://WWW.ncard.org.np/categorydetail/kisan.html.

How to cite: KC, M., \& Singh, N. B. (2020). Ethnomedicinal Knowledge of Kisan Community -A Case Study. Himalayan Journal of Science and Technology, 3-4, 16-23. 